\title{
$\sqrt{1}$

\section{Consecuencias del megaproyecto de dragado de profundización en el sistema socio-ecológico del estuario del Guadalquivir, España}

\author{
Consequences of the Deep Dredging Megaproject \\ on the Socio-Ecological System of the Guadalquivir Estuary, Spain
}

J esús Vargas-Molina

Universidad Pablo de Olavide. Sevilla, España. jvarmol@upo.es

\begin{abstract}
Resumen - La dinámica cortoplacista, sectorial y descoordinada que ha guiado las acciones humanas sobre los recursos del estuario del río Guadalquivir en las últimas décadas ha terminado provocando un importante deterioro del ecosistema y por tanto de los servicios que este puede proporcionar a la sociedad. Para garantizar la sostenibilidad de estos recursos es necesaria, como punto de partida, una visión territorial del estuario basada en la comprensión de las relaciones mediante las que interactúan continuamente el sistema social y el sistema natural. Bajo esta idea se realiza una aproximación del estuario del Guadalquivir hacia el marco de los sistemas socio-ecológicos y se analizan las consecuencias que una planificación sectorial y descoordinada, como la que ejemplifica el megaproyecto de dragado de profundización, puede tener sobre este sistema.

Abstract - The resources of the Guadalquivir estuary have been managed in recent decades by a sectorial, uncoordinated and short-term planning process, resulting in significant damage to ecosystems and therefore to the benefits they are able to provide to society. To ensure the sustainability of these resources a territorial view of the estuary is necessary as a point of departure to understand the constant interaction between social and natural systems. The aim of this essay, therefore, is to link the Guadalquivir estuary to the socio-ecological context, as well as to analyze the consequences that sectorial and uncoordinated planning has on the system, as is the case with the deep dredging megaproject.
\end{abstract}

alabras clave: dragado, Guadalquivir, megaproyecto, sistema socio-ecológico, España
Keywords: dredging, Guadalquivir, megaproject, socio-ecological system, Spain

Información Artículo: Recibido: 3 junio 2013

Revisado: 22 octubre 2013
Aceptado: 13 febrero 2014

(c) Universidad de J aén / Seminario Permanente Agua, Territorio y Medio Ambiente (CSIC) 